\title{
Pre-Extension Demonstration of Improved Haricot Bean Technologies at Midland Districts of Guji Zone, Southern Oromia, Ethiopia
}

\author{
Korji Dembi*, Kebede Basha, Amare Girma \\ Oromia Agricultural Research Institute (IQQO), Bore Agricultural Research Center. P.O.BOX 21, Bore, Ethiopia.
}

How to cite this paper: Korji Dembi, Kebede Basha, Amare Girma. (2021) Pre-Extension Demonstration of Improved Haricot Bean Technologies at Midland Districts of Guji Zone, Southern Oromia, Ethiopia. International Journal of Food Science and Agriculture, 5(2), 285-292. DOI: 10.26855/ijfsa.2021.06.012

Received: March 28, 2021

Accepted: April 23, 2021

Published: May 17, 2021

*Corresponding author: Korji Dembi, Oromia Agricultural Research Institute (IQQO), Bore Agricultural Research Center. P.O.BOX 21, Bore, Ethiopia. Email: korjidembi@gmail.com

\begin{abstract}
Common bean in sub-Saharan Africa is an important crop for food security and nutrition. It plays a big dietary role to both rural and urban households. It is a major food and cash crop in Ethiopia and has substantial national economic. It is often grown as cash crop by smallholder farmers and used as a major food legume in parts of the country where it is consumed in different types of traditional dishes. The value of haricot bean in terms of economic return and food security increases with the use of recently adapted varieties that have better yield and resistance to disease and moisture stress whereas the improved varieties are lacking in the study areas. Therefore, participatory demonstration of improved haricot bean technologies was conducted in two potential midland districts of Guji zone in 2020. The main objective of the study was to popularize improved haricot bean variety at midlands of Guji zone. Adola Rede and Wadera districts were selected based on their potential to grow haricot bean and two peasant associations from each district were selected in criteria of their accessibility. Participatory approach was followed to implement the activity. 15 farmers of gender inclusive were established as FRG at each peasant association. From one FRG, three experimental farmers were nominated based on their consent to provide sufficient and suitable land for experiment. An improved haricot bean of Ibbado variety with one commercial variety was planted on selected farmers' land with a single plot size of 10 $\mathrm{m} \times 10 \mathrm{~m}$. Recommended seed rate of $100 \mathrm{~kg} \mathrm{ha}^{-1}$ with a spacing of $40 \mathrm{~cm}$ and five $\mathrm{cm}$ between rows and plants were used respectively and an inorganic fertilizer (NPS) rate of $100 \mathrm{~kg} \mathrm{ha}^{-1}$ at planting time. Farmers, DAs, SMSs, and different stakeholders were participated on organized training, field visit \&joint monitoring and evaluation and field day on which two-way communication encouraged and experience was shared. Quantitative data such as yield and knowledge change of the farmers were analyzed using independent $t$ test and paired sample $t$ test respectively whereas farmers' feedbacks were analyzed qualitatively. Costs and income gained were analyzed using excel. The result of this study showed that mean difference in knowledge score before and after experiment was significantly higher. An average yield of, 23 quintals ha $^{-1}$ and 12.4 quintals ha ${ }^{-1}$ for improved haricot bean and commercial respectively. The improved variety also revealed a yield advantage of $85.48 \%$ and incremental benefit cost ratio of 19.27 over the commercial. Therefore, recommended for up scaling. However, there is a need for seed of Ibbado variety. So, BoARC should focus on multiplying improved haricot bean of Ibbado variety. Any seed multiplier organizations like unions and cooperatives should give due emphasis for Ibbado seed.
\end{abstract}

\section{Keywords}

Demonstration, Ibbado, Participatory Approach, Midland Districts 


\section{Introduction}

Legume seeds are an important staple foods and sources of dietary minerals that potentially provide all of the 15 essential minerals required by humans. Common bean is the most vital grain legume for direct human consumption. The species have high diversity as seen in its morphological variability, uses and growth habits and patterns [1, 2]. Other names of the common bean include dry bean, kidney bean, haricot bean, French bean and field bean. It is particularly important legume crop grown worldwide. It grows best in warm climates at temperatures of 18 to 240c [3].

Haricot bean plays an imperative role at household level as source of cash, nutrient dense food crop ("poor man's meat") due to its high protein content, which compensates for the deficiency that could have occurred in a population with low income and nitrogen fixer to replenish soil fertility [4].

Haricot bean is an important source of nutrients for more than 300 million people in parts of Eastern Africa and Latin America, representing $65 \%$ of total protein consumed, $32 \%$ of energy and a major source of micro nutrient, E.g. Iron, Zinc, Thiamin and Folic acid [5].

It is described as non-sensitive crop to soil as long as it is well drained and fertile. It can be grown successfully on most soil types, from light sands to heavy clays, but friable, deep and well drained soils are best preferred [6].

According to [7], common bean in sub- Saharan Africa (SSA) is an important crop for food-security and nutrition. It plays a big dietary role, supplying proteins, carbohydrates, essential elements and vitamins to both rural and urban households. It is estimated that the crop meets more than $50 \%$ of dietary protein requirements of households in SSA. The annual per capita consumption is higher among low-income people who cannot afford to buy nutritious food stuff, such as meats and fish [8].

Common bean is also a major food and cash crop in Ethiopia as well and it has considerable national economic significance. It is often grown as cash crop by small scale farmers and used as a major food legume in parts of the country where it is consumed in different types of traditional dishes [9]. For a very long time, it has been cultivated as a field crop. Moreover, it has been an export crop for more than 40 years [10]. Besides, the farmers also grow common bean to use the straw as forage for livestock, source of fuel, mulching, bedding, and covering materials.

The value of Haricot bean in terms of economic return and food security increases with the use of recently adapted varieties that have better yield and resistance to disease and moisture stress. Although there is a general understanding and recognition on the benefit of using improved varieties, the accessibility of improved haricot bean varieties are lacking and farmers are growing unknown varieties in the study areas. This resulted in low productivity of haricot bean. The productivity of haricot bean per unit area could be increased by adopting scientific and suitable management practices using suitable high yielding varieties. As the participatory variety selection trial of haricot bean at multi location and at Adola sub site showed, Ibbado variety was preferred by farmers in its potential to give high yield (27 quintals ha ${ }^{-1}$ ), color, palatability, marketable and disease tolerant [11]. Taking in to account the above considerations, this study was made the first move to demonstrate in a systematic manner on farmers' field to show the worth of new variety and convincing farmers to adapt improved production management practices of haricot bean for enhancing productivity of haricot bean production with the aim of popularizing improved haricot bean variety in midlands of Guji zone.

\subsection{Specific objectives}

The specific objectives of this study were to:

$\checkmark \quad$ Evaluate yield performance of improved haricot bean varieties under farmers' conditions.

$\checkmark$ Assess farmers' feedback for further development of haricot bean production.

$\checkmark \quad$ Evaluate the economic efficiency of improved haricot bean variety.

$\checkmark$ Enhance knowledge and skill of farmers on production of improved haricot bean.

\section{Materials and Methods}

\subsection{Description of the Study Areas}

\subsubsection{Adola Rede District}

The district is located in Southern part of Oromia, Ethiopia, at a distance of $468 \mathrm{~km}$ from Finfinne, the capital of

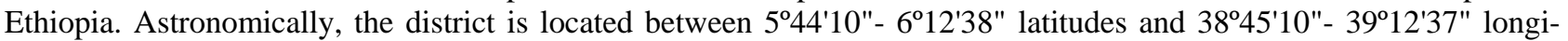
tudes. The district is characterized by three agro-climatic zones, namely humid, sub humid and dry arid zones. In terms of the agricultural calendar, the rain fall pattern of the district is bimodal for lowlands and midland areas and monomodal for highland parts. The dry arid agro-climatic zones attributed to little rainfall while the humid agro-climatic zones receive extremely high rainfall. Rain-fed agriculture is a common practice for many farm households in this district. However, a semi-nomadic economic activity is also practiced as a means of livelihood by some of its dwellers. The farmers of this district produce both in autumn and spring seasons. They produce cereals such as teff, wheat, barley 
and maize, pulses such as haricot bean and others such as fruits and vegetables. Overall, haricot bean, maize and teff are the major crops cultivated by the farmers in these study areas. They also engaged in the production of coffee as means of livelihood.

\subsubsection{Wadera District}

Wadera district is situated at a distance of $535 \mathrm{~km}$ from Finfinne, country capital and $60 \mathrm{~km}$ from the zonal capital town, Negele. Astronomically, the district is located between $5^{\circ} 39^{\prime} 5^{\prime \prime}-6^{\circ} 2 ' 28^{\prime \prime}$ northing latitudes and $39^{\circ} 5^{\prime} 30^{\prime \prime}-39^{\circ} 27^{\prime} 52^{\prime \prime}$ easting longitudes. It is an area where mixed farming economic activities take place, which is the major livelihood of the people. Wadera district is bordered by Bale zone to East, Girja district to North, Adola Rede and Oddo Shakiso districts to the North West and South West respectively and Gorodola district to South East direction. The district is characterized by two types of typical climatic zones, namely, an arid (60\%) and semi-arid (40\%) climate with mean annual temperature ranges from $12 \mathrm{C}^{0}-34 \mathrm{C}^{0}$ and it has a bimodal rainfall pattern. It is the most hot and sub hot condition, which has relatively shorter growing season. The annual rainfall ranges between $915 \mathrm{~mm}$ and up to 1,900 $\mathrm{mm}$.

The district extends from $500 \mathrm{~m}$ and the larger portion of the district lies between $950 \mathrm{~m}$ up to 1,900 $\mathrm{m}$ mean sea level. The long rainy season start from mid-March to May (45-60) days while the short rainy season starts from mid-September to October (30-40 days) in years. The district is drained by Genale, and Sokora Rivers, similarly Banti Stream are the major rivers and streams of the district. The major soils of the district are combo soil, nito soil, fluvial soil, luvisoil, chromic soil, eurtic soil, litho soil are found in the district. The color of the district soil has known as red soil with dominal textures of sand soil. The soil of district for utilization is good under natural vegetation. Generally, teff, maize, haricot bean, wheat, barley are the major crops produced in the district.

\subsection{Sites and Farmers Selection}

Pre-extension demonstration of improved haricot bean technologies was conducted in two potential midland districts of Guji zone, Adola Rede and Wadera. Purposive sampling methods were employed to select two representative districts and two peasant associations from each district based on their potential for haricot bean production and their accessibility.

Participatory approach using Farmers Research Groups (FRGs) were the main strategy used during demonstration of the technologies. Selection of FRGs member farmers was based on farmers' consent to be held as member, accessibility for supervision of activities, good history of harmony with groups and genuineness and transparency to share innovations to other farmers. To this end, one FRG having 15 members with the arrangement of resource rich, medium and poor class of farmers including gender with proportion of at least $70 \%$ to $30 \%$ men and women respectively was established at each peasant association. Three experimental farmers were nominated among FRGs member farmers based on their interest to provide sufficient and suitable land for experiment, vicinity to roads for the chance of being visited by many farmers, initiatives to implement the activity in high-quality, good in field management and willingness to explain the technologies to other farmers and share knowledge, skill and experience for further promotion mechanism. Consequently, three representative experimental farmers were selected at each peasant association from each FRG while the rest FRG member regrouped by their village cluster proportionally.

Table 1. Number of FRG members established in each demonstration site

\begin{tabular}{|c|c|c|c|c|}
\hline \multirow{2}{*}{ Districts (peasant associations) } & \multirow{2}{*}{ No of FRG } & \multicolumn{3}{|c|}{ Composition of FRG members by gender } \\
\hline & & Male & Female & Total \\
\hline Adola Rede ( Kiltu Sorsa and Gobicha) & 2 & 20 & 10 & 30 \\
\hline Wadera (Tulam-Oda Dima and Calo) & 2 & 20 & 10 & 30 \\
\hline Total & 4 & 40 & 20 & 60 \\
\hline
\end{tabular}

\subsection{Materials Used and Field Design}

An improved haricot bean variety (Ibbado) with one commercial variety was planted on selected farmers' land ata plot of $10 \mathrm{~m} \mathrm{x} 10 \mathrm{~m}$ in the main cropping season. The varieties were treated with full recommended haricot bean production and management packages. The recommended seed rate of $100 \mathrm{~kg} \mathrm{ha}^{-1}$ with a spacing of $40 \mathrm{~cm}$ and $10 \mathrm{~cm}$ between rows and plants respectively was used and inorganic fertilizer (NPS) rate of $100 \mathrm{~kg} \mathrm{ha}^{-1}$ at planting time. All agronomic practices and land preparation like ploughing three up to four times using oxen plough, planting, weeding, leveling, harvesting and threshing were carried out by FRGs member farmers.

\subsection{Technology Demonstration and Evaluation Methods}

For the sake of enhancing efficiency and effectiveness, participatory approach was followed. To this end, FRG 
members were encouraged to participate on different extension events organized at each trial site. These were mechanisms used to enhance farmer-to-farmer learning and information exchange such as training, field day, joint monitoring and evaluation like regular field visit by extension agents and extension counterparts at different crop stages.

\subsection{Training of Farmers and Development Agents}

The effectiveness of the work is measured in terms of the changes brought about in the knowledge, skill and attitude, and adoption behavior of the people but not merely in terms of achievements of physical targets. Hence, training is very important to bring improvement on the haricot bean production activities to fill the gap on knowledge, skill and attitude (KSA). Thus on spot training was organized.

\subsection{Field Day}

Field day is a method of motivating people to adopt new practices and variety/es by showing what has already achieved under field conditions. In other words, it is to show the performance and profitability of new practices/technology/innovation and to convince about the applicability. Besides, it is a way of facilitating people to visit new innovation for the purpose of bringing mass mobilization. To this end, mini field day was organized. Besides, regular joint monitoring and evaluation, follow up actions and provision of technical advice were undertaken at different crop stages based on necessary emerging knowledge, skill and technical advice needed.

\subsection{Data Types and Method of Data Collection}

Both qualitative and quantitative data were collected. Seed yield, cost and income gained were recorded. Participants were subjected to simple 'yes' or 'no' and 'open ended' questions prepared regarding the production practices of the haricot bean technologies before and after the demonstration activity and the scores at two occasions (before and after) were recorded out of hundred. Total number of farmers participated on training, field visits and mini field day were recorded by gender composition. Quantitative data was collected using data collection sheets through observation and measurement. Farmers' feedbacks were collected using checklist by conducting group discussion and key informant interviews.

\subsection{Variety Preference Ranking}

The variety preference ranking was conducted using group discussion. The farmers were let to observe and set their own selection criteria at the maturity stage of the crop. The selected criteria were then used to select the preferred variety.

\subsection{Data Analysis}

The collected agronomic data was organized, summarized and analyzed by statistical tool ( $\mathrm{T}$ test). Students $\mathrm{T}$ test was used to compare the mean yield of two varieties. The financial data was employed to analysis the costs incurred and the net benefit gained from the production of each variety and location used for the demonstration using excel and presented by table. The calculations were done by converting the parameters per hectare. The final selling price used was the farm gate selling price during the harvest season. Farmers' variety preference was also analyzed qualitatively. Knowledge level and skills of the participating farmers at pre- and post-experiment about improved variety and production practices was measured and compared by applying dependent $t$ test. The dependent $t$ test is often used to compare 'pre' and 'post' scores in experiment for the determination of the significant change that has occurred. It compares the means of two conditions in which the same (closely matched) participants participated. Two samples are said to be dependent on each other when the elements of one are related to those of the other in any significant or meaningful manner. In fact, the two samples consist of observations made of the same objects, individuals or more generally, on the same selected population elements.

\subsection{Yield Advantage}

The yield advantage of improved haricot bean technology over commercial is calculated in the following formula.

Yield advantage \% of Ibbado $=$ Yield of Ibbado variety - commercial X 100

$$
\text { Commercial }
$$

\section{Results and Discussion}

\subsection{Yield Performance of Demonstrated Varieties}

Table 2 below shows the result of yield performance of the haricot bean varieties demonstrated. According to the results, a mean seed yield of 23 and 12.4 quintals ha ${ }^{-1}$ was obtained from Ibbado and commercial varieties, respectively. 
Table 2. Comparison of mean yield of haricot bean varieties demonstrated

Mean yield of haricot bean varieties demonstrated (quintals ha" ${ }^{-1}$ )

\begin{tabular}{|c|c|c|c|c|c|c|c|}
\hline \multirow{2}{*}{ Varieties } & \multirow{2}{*}{ Mean [Std. Deviation] } & \multirow{2}{*}{$\begin{array}{l}\text { Stad. Error of the } \\
\text { mean difference }\end{array}$} & \multirow{2}{*}{$\begin{array}{l}\text { Calculated t } \\
\text { value }\end{array}$} & \multirow{2}{*}{$\begin{array}{c}\text { Tabulated t value } \\
\text { at v } 22\end{array}$} & \multirow{2}{*}{$P$ value } & \multicolumn{2}{|c|}{$\begin{array}{l}\text { 95\% Confidence } \\
\text { interval }\end{array}$} \\
\hline & & & & & & Lower & Upper \\
\hline Ibbado & $23[0.759]$ & \multirow{2}{*}{0.266} & \multirow{2}{*}{$39.855^{*}$} & \multirow{2}{*}{1.717} & \multirow{2}{*}{0.044} & \multirow{2}{*}{10.401} & \multirow{2}{*}{10.799} \\
\hline Commercial & $12.4[0.523]$ & & & & & & \\
\hline
\end{tabular}

*Significant at 5\% probability level, $\mathrm{v}$ is degree of freedom and std. deviation in parenthesis.

As clearly indicated in Table 2, information such as calculated t value (39.855) greater than the tabulated t value (1.717), the confidence interval does not contain zero value and the $p$ value $(0.044)$ less than the alpha value $(0.05)$. This shows that the mean difference in seed yield between the two varieties were significantly higher. The mean yield of pre-extension demonstration of improved haricot bean variety (Ibbado) was greater than the previous demonstration result, 20.5 quintal ha ${ }^{-1}$ [12]. However, less than the average yield (27 quintals ha $\left.{ }^{-1}\right)$ during the participatory variety selection trial [11]. This yield difference could be associated with disparities in management practices and the fertility status of the soil. Yet the variety still had an extra yield advantage than their commercial check (Table 3).

Table 3. Yield advantage of improved haricot bean variety over the check

\begin{tabular}{ccc}
\hline Varieties & Mean yield (quintal) & Yield advantage of improved haricot bean over the check (\%) \\
\hline Haricot bean & 23 & 85.48 \\
\hline Commercial & 12.4 & \\
\hline
\end{tabular}

\subsection{Feedbacks and Preferences of Farmers}

Farmers' preferences towards the demonstrated haricot bean varieties were assessed by enhancing them to reflect their preference to varietal attributes by setting their own varietal selection criteria. During the course of the demonstration process and at the final stage of the activity, an assessment was made to know how the farmers perceived the technologies. Results of the assessment revealed that improved haricot bean variety liked by farmers as it can survive disease and drought conditions, matures early and attributes for double cropping. Color, marketability and palatability were also the best traits preferred by farmers. Consequently, the participant farmers preferred improved haricot bean variety (Ibbado) as their first choice.

Table 4. Direct matrix ranking of the varieties demonstrated based on farmers preferences $(\mathrm{N}=20)$

\begin{tabular}{|c|c|c|}
\hline Variety & Rank & Reasons \\
\hline Ibbado & $1^{\text {st }}$ & $\begin{array}{c}\text { Very good yield, drought tolerant, disease tolerant, early mature, marketable, } \\
\text { preferred color and palatability }\end{array}$ \\
\hline Commercial & $2^{\text {nd }}$ & $\begin{array}{l}\text { low yield, susceptible to disease, not tolerant to drought, not as such marketable and } \\
\text { its palatability not as such Ibbado }\end{array}$ \\
\hline
\end{tabular}

\subsection{Capacity Development}

On spot trainings on full package of haricot bean production methods and management practices and concepts and principles of Farmer Research Group (FRG) were given to farmers, Development Agents (DAs), and Subject Matter Specialists (SMSs) before starting the activity. Exchange visit was also conducted within FRG group (one sub group with other sub group) and lessons were learnt on the field about the performance of the technologies happened due to strengths and weaknesses of the members in management practices. As indicated in Table 5 below a total of 66 participants attended the training and exchange visit. 
Table 5. Capacity building methods and participants

\begin{tabular}{|c|c|c|c|c|}
\hline \multirow{2}{*}{ Capacity building methods } & \multirow{2}{*}{ Participants } & \multicolumn{3}{|c|}{ Number of participants } \\
\hline & & Male & Female & Total \\
\hline \multirow{3}{*}{ A. On spot training } & Farmers & 40 & 20 & 60 \\
\hline & DAs & 3 & 1 & 4 \\
\hline & SMS & 2 & - & 2 \\
\hline \multirow{2}{*}{ B. Exchange Visit } & Farmers & 8 & 2 & 10 \\
\hline & DAs & 1 & 1 & 2 \\
\hline \multirow{3}{*}{ C. Mini field day } & Farmers & 29 & 11 & 40 \\
\hline & DAs & 3 & 1 & 4 \\
\hline & SMS & 2 & - & 2 \\
\hline \multirow{3}{*}{$\begin{array}{l}\text { D. Joint monitoring and } \\
\text { Evaluation }\end{array}$} & Farmers & 15 & 5 & 20 \\
\hline & DAs & 3 & 1 & 4 \\
\hline & SMSs & 3 & - & 3 \\
\hline
\end{tabular}

\subsection{Monitoring and Evaluation}

The activity was monitored majorly by researchers and Agriculture and Natural Resource Office of the districts which they represented by the development agents (DAs) in the peasant associations. The DAs see and monitor the activity day to day since they are nearer to the farmers' jurisdiction and also give technical assistant to the farmers. Joint monitoring and evaluation of the activities was conducted among the participating farmers of the districts based on the necessities and requirements. As a result, DAs, SMSs and researchers had offered advice based on the practical problem observed on the trial sites.

\subsection{Mini Field Day}

In order to show the performance of the demonstrated haricot bean varieties and create awareness, mini field day was arranged on which FRG member farmers shared experience and knowledge of production about demonstrated haricot bean varieties to the participants. A total of 46 participants were participated (Table 5).

\subsection{Economic Analysis of Haricot Bean Varieties Demonstrated}

Production costs and returns of demonstration of haricot bean varieties were collected from experimental farmers. Production costs included were variable and fixed costs. Variable costs like for land preparation, seed, fertilizer (NPS), planting, weeding, harvesting, threshing, sack and for transaction cost. Fixed cost here was referred to cost for land contract. This cost was included in this experiment as all the farmers in the study areas could not own enough farm land and contract some from their fellow farmers. So, this fixed cost parameter helps us to have insight about the profitability of this crop enterprise as a business for rented farm land as well. During the production season the average fixed cost of farm land for one season was 2,000 ETB ha ${ }^{-1}$ at the study areas. Average farm gate price of improved haricot bean (Ibbado) and commercial varieties during 2020 production season was $25 \mathrm{ETB} \mathrm{Kg}^{-1}$ and $20 \mathrm{ETB} \mathrm{Kg}^{-1}$ respectively. Pre-extension demonstration of improved haricot bean was profitable with net return of 44,387 ETB ha ${ }^{-1}$ and 13,187 ETB ha ${ }^{-1}$ from improved variety (Ibbado) and commercial respectively. As shown in Table 6, the improved variety was more profitable than the commercial variety with incremental benefit cost ratio of more than 15 indicating that with some additional cost to the improved variety, there was higher benefit cost ratio which is economically more feasible over the farmers' (commercial) variety.

Table 6. Economic analysis

\begin{tabular}{ccccc}
\hline Variable & Cost of cultivation & Growth return & Net return & Benefit cost ratio \\
\hline Ibbado & 13,113 & 57,500 & 44,387 & 3.39 \\
Commercial & 12,013 & 25,200 & 13,187 & 1.01 \\
Additional in demonstration & 1,100 & 32,300 & 21,200 & $19.27^{*}$ \\
\hline
\end{tabular}

*Incremental benefit cost ratio. 


\subsection{Knowledge Level Before and After the Trial Period}

Knowledge level and skills of experimental farmers on various aspects of improved haricot bean production technologies before conducting the demonstration and after implementation was measured and compared by applying dependent $t$ test. A list of simple yes or no and open ended questions were designed and administered to a total of 12 experimental farmers to rate their knowledge level before and after the trial period. Farmers were subjected to the same questions at both occasions. The questions were asked during training period before starting the experiment and after the experiment during yield communication. It was revealed in Table 7 that farmers' mean difference in knowledge score before and after implementation of demonstration was 15.75. The mean difference in knowledge score of farmers was observed significantly higher. As the computed value of t (44.34) was statistically significant at $5 \%$ probability level. It means there was significant increase in knowledge level of the farmers due to demonstration. This shows positive impact of demonstration on knowledge of the farmers that have resulted in higher adoption of improved farm practices and improved haricot bean. The results so arrived might be due to the combined effect of concentrated educational efforts made by the researchers and the potential of the improved haricot bean variety, proved itself to give maximum yield.

Table 7. The difference mean score in knowledge levels and skills of respondent farmers to the test questions about improved haricot bean production and its farming practices $(n=12)$

\begin{tabular}{ccccc}
\hline $\begin{array}{c}\text { Mean of the difference in } \\
\text { knowledge scores }\end{array}$ & $\begin{array}{c}\text { Std. deviation of mean difference } \\
\text { in knowledge scores }\end{array}$ & $\begin{array}{c}\text { Stad. Error of mean } \\
\text { difference }\end{array}$ & $\begin{array}{c}\text { Calculated } \mathrm{t} \\
\text { value }\end{array}$ & $\begin{array}{c}\text { Tabulated t value } \\
\text { at } \mathrm{v}=11\end{array}$ \\
\hline 15.75 & 1.23 & 0.093 & $44.34^{*}$ & 1.796 \\
\hline
\end{tabular}

*Significant at $5 \%$ probability level, vis degree of freedom.

\section{Summery, Conclusions and Recommendations}

Despite the widely cultivation of haricot bean in the midland districts of Guji zone, the production and productivity of the crop is very low. The low productivity of haricot bean is stemmed from among others, inaccessibility of improved varieties and poor management practices in the study areas. Taking this in to consideration, the pre-extension demonstration of improved haricot bean technologies was conducted in Adola Rede and Wadera districts purposively because of accessible and potential districts for haricot bean production. The main objective of the study was to popularize improved haricot bean variety at midland districts of Guji zone. Participatory research approaches were followed in implementing the activities. Independent and paired sample $T$ tests, and excel were used to calculate the mean grain yield and change in knowledge level of farmers and economic viability of the demonstrated technologies respectively. The results indicated that the improved variety gave promising yield (23 quintals ha ${ }^{-1}$ ) having a yield advantage of $85.48 \%$ over farmers' (commercial) variety. Furthermore, the improved variety is profitable with incremental benefit cost ratio of 19.27. The skills and knowledge level of participating farmers were found to be changed positively towards the production and management practices of improved haricot bean variety. This was happened due to the concentrated and committed effort of the researchers in imparting knowledge coupled with the attributes of the improved variety, revealed itself to be potential. Based on farmers' preference criteria like yield, drought tolerant, disease tolerant, early maturity, marketability, color and palatability, Ibbado variety was selected as first choice and farmers of the areas were demanding for scaling up and popularization.

Based on the findings of this study the following recommendations were drawn:

The demonstration activity did not ensure the wider popularization of this improved variety as the amount of seed and land used, and number of farmers participated were minimal. Therefore, recommended for up scaling in the midland districts of Guji zone. To do so, it is procedurally allowed to go a step ahead for Agricultural Research Extension Division. However, for the scaling up activity to proceed, Agricultural Research Extension Division of Bore Agricultural Research Center (BoARC) needs to secure seed of Ibbado variety. Hence, BoARC should focus on multiplying Ibbado variety. It is strictly recommended that Office of Agriculture and Natural Resource at zonal level should take these recommendations and aware their fellow office at midland districts the way Ibbado variety of haricot bean could be multiplied. Any seed multiplier organizations like unions and cooperatives should give due emphasis for Ibbado seed. So that farmers in the midland areas could easily access and use haricot bean of Ibbado variety. Any development agents and researchers working with farmers should respect farmers' belief, value and culture and patiently coach farmers the way they could easily understand about the technologies under demonstration.

\section{Acknowledgements}

If this research work were to have no funded by IQQO, the entire work would have been incomplete. Staff of Agriculture and Natural Resource of Adola Rede and Wadera districts and FRG for implementing activities and for our harmony during the stay were also recognized. 


\section{References}

[1] Baeta, P., Pereira, A. M., and Pinheiro, C. (2010). Journal of Food Composition and Analysis Diversity of seed mineral composition of Phaseolus vulgaris L. germplasm. Journal of Food Composition and Analysis, 23: 319-325. http://doi.org/10.1016/j.jfca.2010.01.005.

[2] Heuze, V., Tran, G., Lebas, F., and Noziere, P. (2013). Common bean (Phaseolus vulgaris), Feedipedia.org - Animal Feed Resources Information System-A programme by INRA, CIRAD, AFZ and FAO, http: //www.feedipedia.org/node/266.

[3] Gebre-egziabher Murut, Hadush Tsehaye, and Fetien Abay. (2014). Agronomic performance of some haricot bean varieties (Phaseolus vulgaris L.) with and without phosphorus fertilizer under irrigated and rain fed conditions in the Tigray and Afar regional states, northern Ethiopia. Momona Ethiopian Journal of Science (MEJS), 6(2): 95-109.

[4] Zerhun Ganewo, Tewodros Tefera, and Adane Hirpa. (2017). Determinants of Varietal Replacement of Haricot Bean by Farmers in Boricha District, Southern Ethiopia. Journal of Science \& Development, 5(1).

[5] Petry, N., Boy, E., Wirth, J. P., and Hurrell, R. F. (2015). The Potential of the Common Bean (Phaseolus vulgaris) as a Vehicle for Iron Biofortification. Journal of Nutrients, 7: 1144-1173.

[6] Gifole Gidago, Sheleme Beyene, and Walelign Worku. (2011). The Response of Phaseolus vulgaris L. to Phosphorus Application on Ultisols at Areka, Southern. Journal of Biology, Agricultural and Healthcare, 1(3): 38-50.

[7] Margaret, N., Tenywa, J. S., Otabbong, E., Mubiru, D. N., and Ali, T. (2014). Development of Common Bean (Phaseolus Vulgaris L.) Production Under Low Soil Phosphorus and Drought in Sub-Saharan Africa. Journal of Sustainable Development, 7(5): 128-139.

[8] Arenas, O. R., Huato, M. A., Tapia, J. A., Simon, A. B., Lara, M. H., and Huerta, E. C. (2013). The Nutritional value of Beans (Phaseolus vulgaris L.) and its importance for Feeding of Rural communities in Puebla-Mexico. International Research Journal of Biological Sciences, 2(8): 59-65.

[9] Kedir Oshone, Setegn Gebeyehu, and Kindie Tesfaye. (2014). Assessment of Common Bean (Phaseolus Vulgaris L.) Seed Quality Produced Under Different Cropping Systems By Smallholder Farmers In Eastern Ethiopia. African Journal of Food, Agriculture, Nutrition and Development, 14(1): 8566-8584.

[10] Rahmeto Negash. (2007). Determinants of adoption of improved haricot beans production package in Alaba Special Woreda, Southern Ethiopia, Unpublished M.Sc. thesis, Haramaya University, Ethiopia.

[11] Tekalign, A., Deresa, Sh., Chala, G., Rehoboth, N., Geda, A., and Belachew, D. (2020). Participatory Varietal Evaluation and Selection of Improved Food-type Common Bean (Phaseolus vulgaris L.) varieties in low-midlands of Guji zone, Southern Oromia (unpublished).

[12] Kebede, B., Korji, D., Amare, G. (2018). Participatory Evaluation and Selection of Improved Haricot bean Varieties at Liben District, Lowland Agro Ecology of Guji Zone, Oromia Regional State, Ethiopia. Adv Crop Sci Tech., 6: 332. doi:10.4172/2329-8863.1000332. 